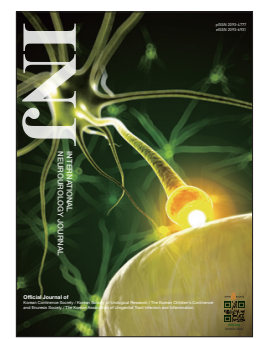

\title{
Potential Epigenetic Biomarkers for Prostate Cancer Screening
}

\author{
Jong-Myon Bae \\ Department of Preventive Medicine, Jeju National University School of Medicine, Jeju, Korea
}

To the editor:

Chiam et al. [1] stated that prostate cancer (PCa) is a major global health problem that imposes a significant economic burden in nations with an aging population. The annual percentage change (APC) of the incidence of PCa in Korean men was 13.7\% from 1999 to 2009, and APC of mortality rates was $17.5 \%$ from 1999 to 2002 [2]. The widespread use of prostate-specific antigen (PSA)-based screening testing (PSA-ST) leads to an increased incidence of $\mathrm{PCa}$ because it enables the earlier detection of occult or asymptomatic disease [3-5].

As PSA is not a specific marker of PCa [1], recommendations on PSA-ST for PCa vary in terms of the screening age and interval [6,7]. Of note, the 2012 U.S. Preventive Services Task Force guideline [8] recommended against routine screening for PCa, because the benefits of PSA-ST for PCa do not outweigh the harms.

The harms of PSA-ST can be summarized as overdiagnosis, unnecessary biopsies with potential associated adverse effects, anxiety, and excessive treatment $[7,9,10]$. As such, the most serious limitation of PSA-ST as a screening modality is the fact that PSA levels can be elevated in patients with benign prostatic hyperplasia or prostatitis, as well as in PCa patients [7,11]. This phenomenon may give rise to overdiagnosis, resulting in overtreatment $[1,6,12,13]$. In addition to this, PSA-ST has very poor sensitivity, specificity, and predictive values because there are no absolute cutoff PSA levels defining PCa $[1,13]$. Thus, Lee et al. [14] concluded that PSA-ST alone did not increase earlystage PCa detection or reduce mortality.

To overcome these limitations of PSA-ST, PSA velocity [15], testing for 4 prostate-specific kallikreins [3], the prostate health index test [16], the percentage of free PSA [17], and tests for noncoding prostate-tissue-specific RNA [18] have been introduced. However, these PSA derivatives may be impractical or only helpful in specific situations $[1,7]$. Thus, novel biomarkers capable of replacing serum PSA for PCa screening must be investigated [19-22]. In addition, reliable and accurate biomarkers for discriminating between indolent and aggressive tumors at the early stage of PCa are needed [23].

As age, race, and environment are known to be the main risk factors for PCa, epigenetic studies investigating the carcinogenesis of PCa through gene-environment interactions have been conducted [1,24]. Current evidence suggests that epigenetic alterations of aberrant DNA methylation, histone modifications, and noncoding microRNA are associated with the carcinogenesis of PCa [25-28]. Thus, potential biomarkers related to a high frequency of epigenetic changes may improve the sensitivity and specificity of the diagnosis (including early detection) and prognosis of PCa $[1,13,25,27,29]$.

Chiam et al. [1] tabulated the epigenetic biomarkers associated with the diagnosis, prognosis, and treatment response of PCa. Furthermore, Yegnasubramanian [13] suggested that methylation in the regulatory regions of GSTP1, APC, PTGS2, $R A R B$, and RASSF1A may be epigenetic biomarkers for PCa screening. In particular, measurements of GSTP1 promoter methylation in plasma, serum, whole blood, urine, ejaculate, or prostatic secretions may complement PSA-ST for PCa based on a meta-analysis of 22 studies [30]. However, all those studies were case-control studies with a small sample size. Thus, a population-based cohort study in asymptomatic men with a large sample size is needed to evaluate the effectiveness of GSTP1 for the early detection of PCa and/or the identification of aggressive tumors.

Corresponding author: Jong-Myon Bae (iD https://orcid.org/0000-0003-3080-7852 Department of Preventive Medicine, Jeju National University School of Medicine, 102 Jejudaehak-ro, Jeju 63243, Korea

E-mail: jmbae@jejunu.ac.kr / Tel: +82-64-755-5567 / Fax: +82-64-758-3231

Submitted: April 11, 2018 / Accepted after revision: May 24, 2018

cC (1) \$ This is an Open Access article distributed under the terms of the Creative Commons Attribution Non-Commercial License (http://creativecommons.org/licenses/by-nc/4.0/) which permits unrestricted non-commercial use, distribution, and reproduction in any medium, provided the original work is properly cited. 
In conclusion, the controversies regarding PSA-ST have led to the need for a more accurate biomarker suitable for the early detection of PCa [31]. This unmet need could be satisfied by epigenetic biomarkers related to the pathogenesis of $\mathrm{PCa}$ $[13,29]$.

However, potential epigenetic markers require further research to be validated for screening in diverse populations $[25,32]$. Further studies may lead to the development of epigenetic markers that could replace, rather than complement, PSAST due to advantages in sensitivity.

- Conflict of Interest: No potential conflict of interest relevant to this article was reported.

\section{REFERENCES}

1. Chiam K, Ricciardelli C, Bianco-Miotto T. Epigenetic biomarkers in prostate cancer: Current and future uses. Cancer Lett 2014;342: 248-56.

2. Jung KW, Won YJ, Kong HJ, Lee ES; Community of PopulationBased Regional Cancer Registries. Cancer statistics in Korea: incidence, mortality, survival, and prevalence in 2015. Cancer Res Treat 2018;50:303-16.

3. Eastham J. Prostate cancer screening. Investig Clin Urol 2017;58: 217-9.

4. Welch HG, Black WC. Overdiagnosis in cancer. J Natl Cancer Inst 2010;102:605-13.

5. Bae JM. Epidemiological evidences on overdiagnosis of prostate and kidney cancers in Korean. Epidemiol Health 2015;37:e2015015.

6. Pinsky PF, Prorok PC, Kramer BS. Prostate cancer screening - a perspective on the current state of the evidence. N Engl J Med 2017; 376:1285-9.

7. Stewart RW, Lizama S, Peairs K, Sateia HF, Choi Y. Screening for prostate cancer. Semin Oncol 2017;44:47-56.

8. Moyer VA; U.S. Preventive Services Task Force. Screening for prostate cancer: U.S. Preventive Services Task Force recommendation statement. Ann Intern Med 2012;157:120-34.

9. Loeb S. Evidence-based versus personalized prostate cancer screening: using baseline prostate-specific antigen measurements to individualize screening. J Clin Oncol 2016;34:2684-6.

10. Ruane-McAteer E, Porter S, O'Sullivan JM, Santin O, Prue G. Active surveillance for favorable-risk prostate cancer: Is there a greater psychological impact than previously thought? A systematic, mixed studies literature review. Psychooncology 2017;26:1411-21.

11. Roehrborn CG, Boyle P, Gould AL, Waldstreicher J. Serum pros- tate-specific antigen as a predictor of prostate volume in men with benign prostatic hyperplasia. Urology 1999;53:581-9.

12. Mundbjerg K, Chopra S, Alemozaffar M, Duymich C, Lakshminarasimhan R, Nichols PW, et al. Identifying aggressive prostate cancer foci using a DNA methylation classifier. Genome Biol 2017;18:3 .

13. Yegnasubramanian S. Prostate cancer epigenetics and its clinical implications. Asian J Androl 2016;18:549-58.

14. Lee YJ, Park JE, Jeon BR, Lee SM, Kim SY, Lee YK. Is prostate-specific antigen effective for population screening of prostate cancer? A systematic review. Ann Lab Med 2013;33:233-41.

15. Lee HW, Kwak KW, Choi YH, Choi HY, Lee HM. New thresholds for prostate-specific antigen velocity for prostate cancer screening in Korean patients younger than 60 years old. Korean J Urol 2008; 49:113-7.

16. Catalona WJ, Partin AW, Sanda MG, Wei JT, Klee GG, Bangma $\mathrm{CH}$, et al. A multicenter study of [-2]pro-prostate specific antigen combined with prostate specific antigen and free prostate specific antigen for prostate cancer detection in the 2.0 to $10.0 \mathrm{ng} / \mathrm{mL}$ prostate specific antigen range. J Urol 2011;185:1650-5.

17. Lee R, Localio AR, Armstrong K, Malkowicz SB, Schwartz JS; Free PSA Study Group. A meta-analysis of the performance characteristics of the free prostate-specific antigen test. Urology 2006;67:7628.

18. Wei JT, Feng Z, Partin AW, Brown E, Thompson I, Sokoll L, et al. Can urinary PCA3 supplement PSA in the early detection of prostate cancer? J Clin Oncol 2014;32:4066-72.

19. Endzeliņ̌̌ E, Melne V, Kalniņa Z, Lietuvietis V, Riekstiņa U, Llorente $A$, et al. Diagnostic, prognostic and predictive value of cell-free miRNAs in prostate cancer: a systematic review. Mol Cancer 2016; 15:41.

20. Shariat SF, Semjonow A, Lilja H, Savage C, Vickers AJ, Bjartell A. Tumor markers in prostate cancer I: blood-based markers. Acta Oncol 2011;50 Suppl 1:61-75.

21. Bjartell A, Montironi R, Berney DM, Egevad L. Tumour markers in prostate cancer II: diagnostic and prognostic cellular biomarkers. Acta Oncol 2011;50 Suppl 1:76-84.

22. Roobol MJ, Haese A, Bjartell A. Tumour markers in prostate cancer III: biomarkers in urine. Acta Oncol 2011;50 Suppl 1:85-9.

23. Dmitriev AA, Rosenberg EE, Krasnov GS, Gerashchenko GV, Gordiyuk VV, Pavlova TV, et al. Identification of novel epigenetic markers of prostate cancer by NotI-Microarray analysis. Dis Markers 2015;2015:241301.

24. Chinaranagari S, Sharma P, Bowen NJ, Chaudhary J. Prostate cancer epigenome. Methods Mol Biol 2015;1238:125-40.

25. Jerónimo C, Bastian PJ, Bjartell A, Carbone GM, Catto JW, Clark 
SJ, et al. Epigenetics in prostate cancer: biologic and clinical relevance. Eur Urol 2011;60:753-66.

26. Kgatle MM, Kalla AA, Islam MM, Sathekge M, Moorad R. Prostate cancer: epigenetic alterations, risk factors, and therapy. Prostate Cancer 2016;2016:5653862.

27. Yang M, Park JY. DNA methylation in promoter region as biomarkers in prostate cancer. Methods Mol Biol 2012;863:67-109.

28. Geybels MS, Zhao S, Wong CJ, Bibikova M, Klotzle B, Wu M, et al. Epigenomic profiling of DNA methylation in paired prostate cancer versus adjacent benign tissue. Prostate 2015;75:1941-50.

29. Blute ML Jr, Damaschke NA, Jarrard DF. The epigenetics of pros- tate cancer diagnosis and prognosis: update on clinical applications. Curr Opin Urol 2015;25:83-8.

30. Wu T, Giovannucci E, Welge J, Mallick P, Tang WY, Ho SM. Measurement of GSTP1 promoter methylation in body fluids may complement PSA screening: a meta-analysis. Br J Cancer 2011;105:65-73.

31. Troyer DA, Mubiru J, Leach RJ, Naylor SL. Promise and challenge: markers of prostate cancer detection, diagnosis and prognosis. Dis Markers 2004;20:117-28.

32. Wu Y, Sarkissyan M, Vadgama JV. Epigenetics in breast and prostate cancer. Methods Mol Biol 2015;1238:425-66. 